\title{
Aaron J. Kogon, Jean-Philippe Fontaille, The Coinage of Herod Antipas: A Study and Die Classification of the Earliest Coins of Galilee (Ancient Judaism and Early Christianity - 102), Brill, Leiden-Boston 2018, 123 pp., 40 b/w plates, ISSN 1871-6636; ISBN 978-90-0435961-1
}

The coins minted in the area of ancient Palestine are a constant object of desire for collectors and of interest to scholars. Collectors tend to be motivated by an interest in the political and religious history of the region. For scholars, meanwhile, these coins can often be a source of information about hitherto unknown historical facts. The reason for this is not only the nature of coins as a historical source, but the major diversity of types deriving from various time periods. This variety results from the fact that throughout history numerous mints were operating in Palestine, which itself for long periods was dependent on powerful neighbours whose coins were used in the territory. Studies on Palestine's mints have a long tradition, and this no doubt makes it easier for scholars to delineate new directions of research. These are also possible to implement as a result of collections - privately held and in museums - as well as archaeological excavations. The coins found in the course of digs can be precisely dated, which allows us to determine the approximate time of issue of the various types and the extent of their circulation, ${ }^{1}$ but also, thanks to die study, to trace the changes occurring during the production of coins as stamps were used up. This particular issue has been the subject of interest of Jean-Philippe Fontanille in recent years, resulting in the publication in 2012, together with Donald T. Ariel, of a book devoted to Herod's coinage. ${ }^{2}$ Fontanille's next book, co-written with Aaron J. Kogon devoted to the minting of Herod Antipas, was published in 2018. This work is a rather slim volume, limited by the relatively low number of surviving coins of Herod Antipas, rendering making die study impossible. Yet the book is important for various groups of scholars dealing with ancient Palestine, as it is the first extended and comprehensive study of this ruler's coinage. Some 788 specimens struck from 81 obverses and 222 die reverses are analysed, representing 21 types of Herod Antipas' coins.

The book comprises ten chapters (1. "Introduction" (pp. 1-7); 2. "The Coins" (pp. 8-11); 3. "Denominations and Metrologies" (pp. 12-15); 4. "Chronology" (pp. 16-20);

1 Cf. D. Syon, Small Change in Hellenistic-Roman Galilee: Evidence from Numismatic Site Finds as a Tool for Historical Reconstruction, Jerusalem 2015.

2 D. T. Ariel, J.-P. Fontanille, The Coins of Herod: A Modern Analysis and Die Classification, LeidenBoston 2012. 
5. "Mints" (pp. 21-22); 6. "Dies and Minting" (pp. 23-32); 7. "Inscriptions" (pp. 3338); 8. "The Iconography" (pp. 39-51); 9. "Geographical Distribution" (pp. 52-59); 10. "The Legacy of Antipas' Coins" (pp. 60-63), two appendices (Appendix A: "Tooled and Forged Coins," pp. 65-67; Appendix B: "Provenanced Finds," pp. 68-72), a bibliography, 40 plates of illustrated die study results (pp. 81-121), and an index.

A researcher interested in the history of the members of the Herod family, and especially the fortunes of the lands they ruled, will find many worthwhile observations in this book resulting from analysis of Herod Antipas' coinage. These provide a much better insight into his activity as ruler than written sources. The chronology of the issue of Antipas' coins does not cause any particular problems, since six series of his coins (A-F; comprising 21 types of coins of four denominations) bear the dates when they were struck (p. 18, tab. 41.1). The authors attempt to connect the issues of individual series with the events that might have justified them, but as they admit, this is not always possible. The fundamental reason for local rulers to mint coins was the need for them to finance their own spending. Analysed from this point of view, Herod Antipas' minting leads the authors to the conclusion that the objective of the issue of series B (with the legend TIBERIAS dated to 20-21 CE) might have been to cover part of the costs of building his new capital (pp. 17, 19). The date of this issue and its connection with the development of Tiberias suggests that this city was founded in 20/21 CE (pp. 21-22). Meanwhile, the likely reason for the issue of series F, dated to 39/40 CE with a new type of obverse and reverse and an inscription addressed to the emperor Gaius (Caligula), was a desire to please the emperor (p. 37). This issue is also important for one more reason. It was minted in the $43^{\text {rd }}$ year of the reign of Herod Antipas, who soon afterwards was stripped of power by Gaius, meaning that we can be more precise than previously in determining when this took place. With the exception of the first series of Herod Antipas' coins, which was probably minted in Sepphoris, all the others come from the mint in Tiberias (pp. 21-22). Based on a die study, the authors concluded that during Antipas' reign the mint in Tiberias may have struck 1 to 5 million coins, although they regard the first of these figures as the more likely (p. 27). The statistics of all the types of coins from the various series suggests that a similar number were minted (pp. 28-31).

The iconography of the coins of Herod Antipas is limited to traditional Jewish themes and symbols (pp. 42-51), which demonstrates that he abided consistently by the rules of aniconism, even on coins with an inscription dedicated to the emperor (pp. 39-42). This practice may prove that he was trying to avoid a potential source of conflict with Jews, of whom there must have been a significant number among his subjects. Despite this caution, he did not manage to avoid such conflict, albeit for a different reason. It is worth adding here that on the coins classified as type 14 , the authors managed to identify a star as an entirely new iconographic element of Herod Antipas' coins, yet without being able to point definitely to its meaning (pp. 47-50).

The authors regard the views expressed by certain scholars - that Herod Antipas' minting contributed to the monetisation of Galilee - as an exaggeration, although it certainly had an influence on its economy. The findings of this ruler's coins in excavations leave no doubt as to the local character of their circulation, limited to Galilee, Gaulanitis and the Decapolis, territories which he ruled (pp. 54-59 and p. 54, Fig. 9.2). Of the 146 coins of Herod Antipas deriving from excavations, only four were found outside of Gali- 
lee (one in Jerusalem, one in Jericho and two in Caesarea Maritima) (p. 53, Fig. 9.1). Appendix B (pp. 68-72) contains a complete list of finds of these coins (including the place of discovery, minting year, denomination, place of publication and Israel Antiquities Authority inventory number).

The authors also note the influence of Herod Antipas' coinage on that of the Roman administration of Judaea. In 53/54 CE the mint in Tiberias struck coins with the name of Emperor Claudius modelled on series C-E of Herod Antipas. The models of the same ruler's coins were also used later by Agrippa II, as well as the insurrectionary mint in Gamla (pp. 60-63).

Beyond any doubt, the authors' innovative methods of analysis of the technical aspects of Herod Antipas' coinage mean that Aaron J. Kogon's and Jean-Philippe Fontanille's book deserves its place in the library of every scholar interested in the minting of the Herods. It can also be recommended to anyone with an interest in the history of Judaea. Although they will not find any conclusions heralding significant changes to the picture that has been known for a long time, the observations on Herod Antipas' minting that the book contains will add important details to their knowledge of his activity.

Edward Dąbrowa (Jagiellonian University in Kraków) 